\title{
Effect of Exercise on Oxidant and Antioxidant Systems in Rat Kidney Tissue with Hyperthyroidism
}

\author{
Hilal Üstündağ $\breve{12}^{1,2} \quad$ Serap Yıldırım $^{2} \quad$ Esra Şentürk $^{2,3} \quad$ Elvin Aliyev $^{4} \quad$ Abdükadir Yıldırım $^{4}$ \\ 1.Department of Physiology, School of Medicine, Erzincan Binali Yildirim University Erzincan, Turkey \\ 2. Department of Physiology, School of Medicine Ataturk University, Erzurum, Turkey \\ 3. Department of Nursing, Faculty of Health Sciences, Agri İbrahim Cecen University, Agri, Turkey \\ 4. Department of Biochemistry. Ataturk University. School of Medicine. Erzurum, Turkey
}

\begin{abstract}
Oxidative stress is involved in the pathogenesis of many diseases. Hyperthyroidism is associated with increased oxidative tissue damage. The aim of this study is to investigate whether if there is any protective effect of a regular endurance exercise on oxidative stress in kidney tissues of rats with experimental hyperthyroidism. Twenty-three male Spraque Dawley rats were divided into four groups: Control, hyperthyroid, exercise and, hyperthyroid with exercise. Hyperthyroid was induced in rats by subcutaneous injections at a dosage of $250 \mu \mathrm{g}$ L-thyroxine per kg body weight and hyperthyroidism was confirmed by the measurements of TSH, $\mathrm{FT}_{3}$ and $\mathrm{FT}_{4}$ in serum. Endurance training lasted 8 weeks and consisted of 45 minutes daily treadmill running at a speed of 23 $\mathrm{m} /$ minute for 5 days a week. The levels of MDA, GSH and, GSH-Px activity were measured in kidney homogenates. MDA level of the hyperthyroid group was significantly higher than those of the control $\operatorname{group}(\mathrm{p}=0.022)$. On the other hand, the MDA level of the exercise group was significantly lower than the MDA level of the hyperthyroid group $(\mathrm{p}=0,001)$. GSH level and GSH-Px activities were lower in the hyperthyroid group comparing the control group $(\mathrm{p}<0.05)$. GSH level and GSH-Px activity in the exercise group were higher than compared with the hyperthyroid group $(\mathrm{p}<0.05)$. The results of our study show that L-thyroxine injection may increase oxidative stress by causing lipid peroxidation at kidney tissues and endurance training may decrease oxidative stress.
\end{abstract}

Keywords: Endurance training, glutathione, glutathione peroxidase, hyperthyroidism, kidney tissue, malondialdehyde

DOI: $10.7176 / \mathrm{JMPB} / 70-05$

Publication date: April $30^{\text {th }} 2021$

\section{Introduction}

Thyroid gland is one of the largest endocrine glands in the body, which secretes thyroxine and triiodothyronine hormones called $\mathrm{T}_{4}$ and $\mathrm{T}_{3}$. The most common effect of thyroid hormones in many mammal species is that tissues increase the metabolic rate and rate of oxygen use (1-3). Thyroid hormones show this effect on energy metabolism by making many changes in the activity and number of some mitochondrial respiratory chain components including oxygen consumption and oxidative phosphorylation. Accelerated mitochondrial electron transport caused by hypermetabolic condition induced by thyroid hormone results in an increase in the formation of superoxides in the ubiquinone region $(3,4)$. The resulting superoxide radicals lead the formation of many reactive species, including hydroxyl radicals, which rapidly initiate the free radical process of lipid peroxidation (3). Thyroid hormones increase the oxidative system by inducing basal metabolic rate and specific mitochondrial enzymes, resulting in free radical formation (5). Hyperthyroidism, on the other hand, increases these effects (3).

Free radicals are compounds that affect all important components of cells such as lipid, protein, carbohydrates and DNA, produced in a significant amount in the body, carrying one or more unshared electrons in the outer orbits and showing reactive properties. Free oxygen radicals cause peroxidation of membrane phospholipids in the pathogenesis of tissue destruction in many pathological conditions. The most important of its harmful effects is the oxidation of poly unsaturated fatty acids. Hydroxyl, singlet oxygen and superoxide radicals and peroxyl and alkoxylate radicals play a role in oxidation $(6,7)$. There are some mechanisms in cells that prevent, destroy or partially reduce oxidative damage. The substances that inactivate oxidants with direct effect are antioxidants. The antioxidant defense system performs the protective role during the functioning of normal metabolism. The balance during the formation and removal of free radicals in the body is maintained by this antioxidant defense system. If the situation deteriorates in favor of the radical formation, the body may face many diseases $(8,9)$.

In addition to physical exercise having many beneficial effects on health, there are also indications that reactive oxygen types and free radical formation increase especially during severe exercise and that oxidative damage occurs in muscles, liver, blood and other tissues (10). Oxidative damage related to physical exercise depends on the type and intensity of exercise. The higher the intensity of exercise, the greater the formation of oxidative stress and free radicals. While it is specified that especially acute, intensive exercises is cause oxidative stress, it is suggested that regular endurance training reduces oxidative stress and muscle damage after exercise 
and improves antioxidant defense capacity(11).

The effects of thyroid hormones on metabolic pathways are well known, however, in studies carried out to this day, the effects of thyroid hormone deficiency or excess on lipid peroxidation and antioxidant system have not been clearly revealed. The presence of conflicting results in studies on this subject, and the limited numbers of studies carried out on people suggest that the issue should be investigated more thoroughly.

In this study, it was investigated whether regular endurance exercise has any effect on some oxidative stress parameters in the kidney tissue of rats with hyperthyroidism. With this purpose, malondialdehyde (MDA) and glutathione (GSH) levels and glutathione peroxidase (GSH-Px) enzyme activity were measured and compared between groups in the homogenates of kidney tissue of rats in which hyperthyroidism was created.

\title{
Materials and Methods
}

It was approved by the Local Ethics Board of Animal Experiments at Ataturk University, with the document numbered: B.30.2.ATA.0.A1.-2465 that all stages of the study comply with the ethical rules.

\begin{abstract}
Animals
In our study, 23 Spraque-Dawley male rats ranging from 200-220 grams to 200-220 grams of average weight obtained from Atatürk University Medical Experimental Research and Application Center (ATADEM) were used. During the experiment, all animals were kept at room temperature of $24 \pm 1{ }^{\circ} \mathrm{C}$, in a 12-hour light/dark light cycle, in environments with a humidity of 50-60\%, fed with standard pellet feed and tap water and kept in the same environmental conditions.
\end{abstract}

\section{Experimental procedure and groups}

In the study, 23 randomly selected experimental animals from among adult male Spraque-Dawley rats were divided into four groups; control $(n=6)$, hyperthyroidism $(n=5)$, exercise $(n=6)$, and hyperthyroidism+exercise $(n=6)$. Rats in the control group were administered $0.5 \mathrm{ml}$ subcutaneous isotonic $\mathrm{NaCl}$ solution every day and ran for 5 minutes on the treadmill for 8 weeks, 5 days a week.

During the experiment, rats in the hyperthyroidism group were administered a subcutaneous L-thyroxine injection at a dose of $250 \mu \mathrm{g} / \mathrm{kg}$ every day (12). Rats in the exercise group were administered $0.5 \mathrm{ml}$ subcutaneous isotonic $\mathrm{NaCl}$ solution every day and ran for 45 minutes at a speed of $23 \mathrm{~m} / \mathrm{min}$ on the treadmill for 8 weeks, 5 days a week. During the $(5,13,14)$ experiment hyperthyroidism was created in the rats in the hyperthyroidism+exercise group, by performing $250 \mu \mathrm{g} / \mathrm{kg}$ dose of subcutaneous L-thyroxine injection every day and the rats ran for 45 minutes on the treadmill at a speed of $23 \mathrm{~m} / \mathrm{min}, 5$ days a week for 8 weeks.

\section{Tissue Preparation and Biochemical Analysis}

At the end of the experimental procedures, each rat was put to sleep with ether inhalation, and intracardiac blood samples were taken immediately after the rib cage was opened. The kidney tissues removed were washed with cold physiological saline solution and homogenized by mechanical homogenizer after removing wetness with drying paper. Then, after being centrifuged for 15 minutes at $7800 \mathrm{xg}$ at $4{ }^{\circ} \mathrm{C}$, the supernatants were aliquoted and kept at $-80^{\circ} \mathrm{C}$; the blood samples were centrifuged for 10 minutes at $1000 \mathrm{x} \mathrm{g}$ at $4{ }^{\circ} \mathrm{C}$ and their serums were obtained.

Malondialdehyde (MDA) determination in kidney tissue samples was done with the MDA, TBARS method spectrophotometrically at $532 \mathrm{~nm}$ as described by Ohkawa and colleagues (15). Glutathione peroxidases (GSHPx) activity and glutathione (GSH) determinations in kidney tissues was done by using a commercial kit, according to the manufacturer's measurement instructions (Glutathione Peroxidase Assay Kit Item No: 703102 , Glutathione Assay Kit. item No. 703002 Cayman Chemical). The determination of Blood TSH, FreeT3 and FreeT4 was done by using commercial ELISA kits (FeeT3 Kat. No: CSB-E05076r, FreeT4 Kat. No: CSBE05079r, TSH Kat No: CSB-E050115r, CUSABIO BIOTECH) in accordance with the measurement recommendations of the manufacturer.

\section{Statistical analysis}

Statistical analysis was conducted with the SPSS 18.0 (SPSS Inc., Chicago, IL). In the study, the FT3, FT4, MDA, GSH, GSH-PX values of the experimental groups were identified as numeric variables. The normal distribution of data was evaluated by Kolmogorov-Smirnov test. Student-t test was used in cross-group comparisons. Differences with $\mathrm{P}<0.05$ were considered statistically significant.

\section{Results}

Respectively, weight changes in rats in study groups were shown in Table 1, serum Free T3, Free T4 and TSH concentrations were shown in Table 2, and oxidative stress parameter levels measured in kidney tissue were shown in Table 3. 
Table 1. Weight changes of rats during the study

\begin{tabular}{ccccc}
\hline \multirow{2}{*}{ Groups } & \multicolumn{4}{c}{ Rat Body Weight (gr) } \\
\cline { 2 - 5 } & $\begin{array}{c}\text { First Weighing } \\
\text { (1st Day) }\end{array}$ & $\begin{array}{c}\text { Last Weighing } \\
(8 \text { th Week })\end{array}$ & Difference & $\%$ \\
\hline Control $(\mathrm{n}=6)$ & 257 & 306 & +49 & 19.06 \\
\hline Hyperthyroidism $(\mathrm{n}=5)$ & 278 & 254 & -24 & 8.63 \\
\hline Exercise $(\mathrm{n}=6)$ & 231 & 261 & +30 & 12.98 \\
\hline $\begin{array}{c}\text { Hyperthyroidism+Exercise }(\mathrm{n}=6) \\
(\mathrm{H}+\mathrm{E})\end{array}$ & 244 & 265 & +21 & 8.60 \\
\hline
\end{tabular}

Table 2. Plasma T3, FT4 and TSH concentrations of rats in study groups. Parameters Groups

\begin{tabular}{ccccc}
\cline { 2 - 4 } & Control & Hyperthyroidism & Exercise & $\begin{array}{c}\text { Hyperthyroidism }+ \\
\text { Exercise }\end{array}$ \\
\hline TSH $(\mu \mathrm{U} / \mathrm{mL})$ & $1.54 \pm 0.34$ & $0.82 \pm 0.16$ & $1.71 \pm 0.78$ & $0.83 \pm 0.09$ \\
\hline FT3 $(\mathrm{pg} / \mathrm{mL})$ & $2.07 \pm 0.31$ & $2.96 \pm 0.47$ & $2.44 \pm 0.59$ & $2.89 \pm 0.45$ \\
\hline FT4 $(\mathrm{pmol} / \mathrm{L})$ & $7.99 \pm 0.79$ & $11.23 \pm 1.35$ & $9.04 \pm 0.85$ & $11.60 \pm 1.72$ \\
\hline
\end{tabular}

Table 3. Oxidative Stress Parameter Levels Measured in Kidney Tissue.

\begin{tabular}{llll}
\hline Groups & $\mathrm{MDA}(\mu \mathrm{mol} / \mathrm{L})$ & GSH-Px $(\mathrm{U} / \mathrm{mL})$ & GSH $(\mu \mathrm{mol} / \mathrm{L})$ \\
\hline Control & $22.53 \pm 4.22$ & $70.68 \pm 10.10$ & $148.10 \pm 14.83$ \\
\hline Hyperthyroidism & $29.99 \pm 5.28^{\mathrm{a}}$ & $51.13 \pm 7.36^{\mathrm{a}}$ & $110.68 \pm 15.6^{\mathrm{a}}$ \\
\hline Exercise & $18.47 \pm 3.61^{\mathrm{b}}$ & $71.59 \pm 11.33^{\mathrm{b}}$ & $134.31 \pm 10.84^{\mathrm{b}}$ \\
\hline $\mathrm{H}+\mathrm{E}$ & $19.95 \pm 2.40^{\mathrm{b}}$ & $58.3 \pm 9.79$ & $121.51 \pm 35.45$
\end{tabular}

${ }^{\mathrm{a}} \mathrm{p}<0.05$ Compared to the control group,

${ }^{\mathrm{b}} \mathrm{p}<0.05$ Compared to hyperthyroidism.

Regarding weight changes in experimental groups, as presented in Table 1 and Figure 1, according to the results obtained, weight loss occurred in the hyperthyroidism group, while the hyperthyroidism+exercise group, which exercised, tried to maintain the current body weight with an increase of $8.6 \%$.

Thyroid status was determined by changes in body weight as shown in Table 1 and Figure 1 and plasma FT3, FT4, TSH levels as shown in Table 2. When the results from all experimental groups are compared, average weight loss of $24 \mathrm{~g}$, the increase in plasma FT3, FT4 levels and the decrease in TSH levels in the rats in hyperthyroidism group indicates that experimental hyperthyroidism has occurred.

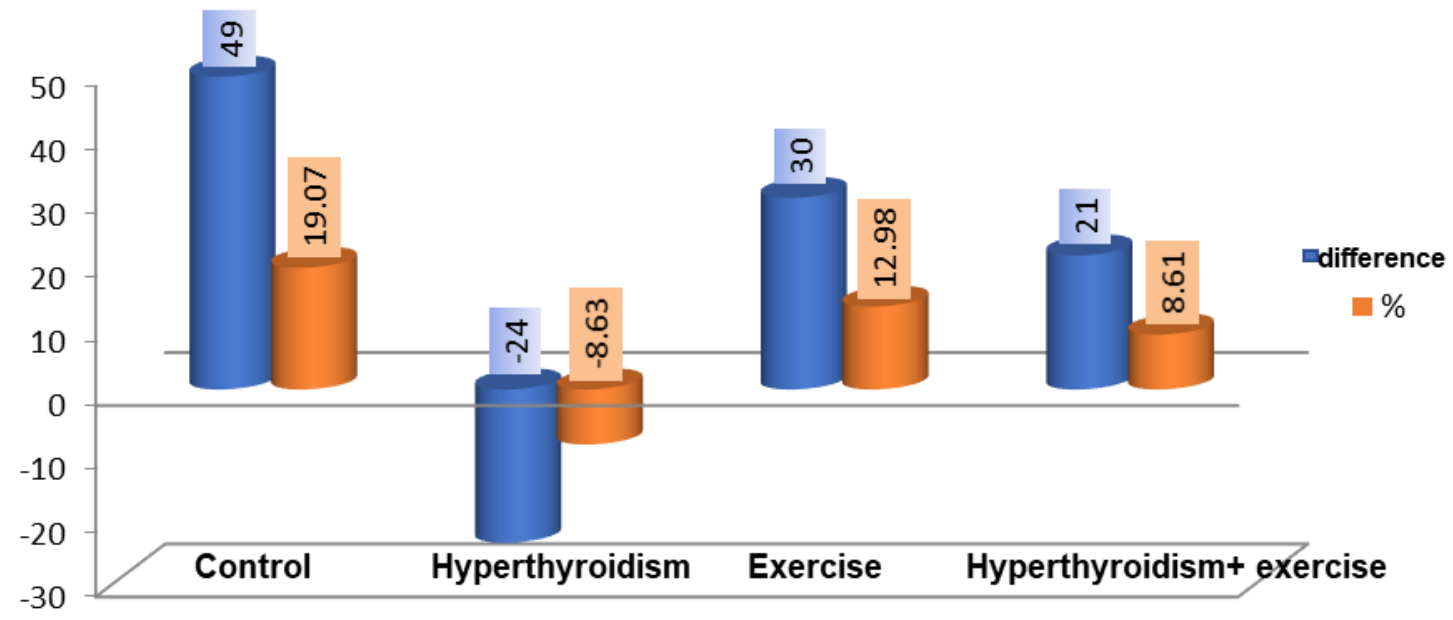

Figure 1. Weight change in the studied groups. 


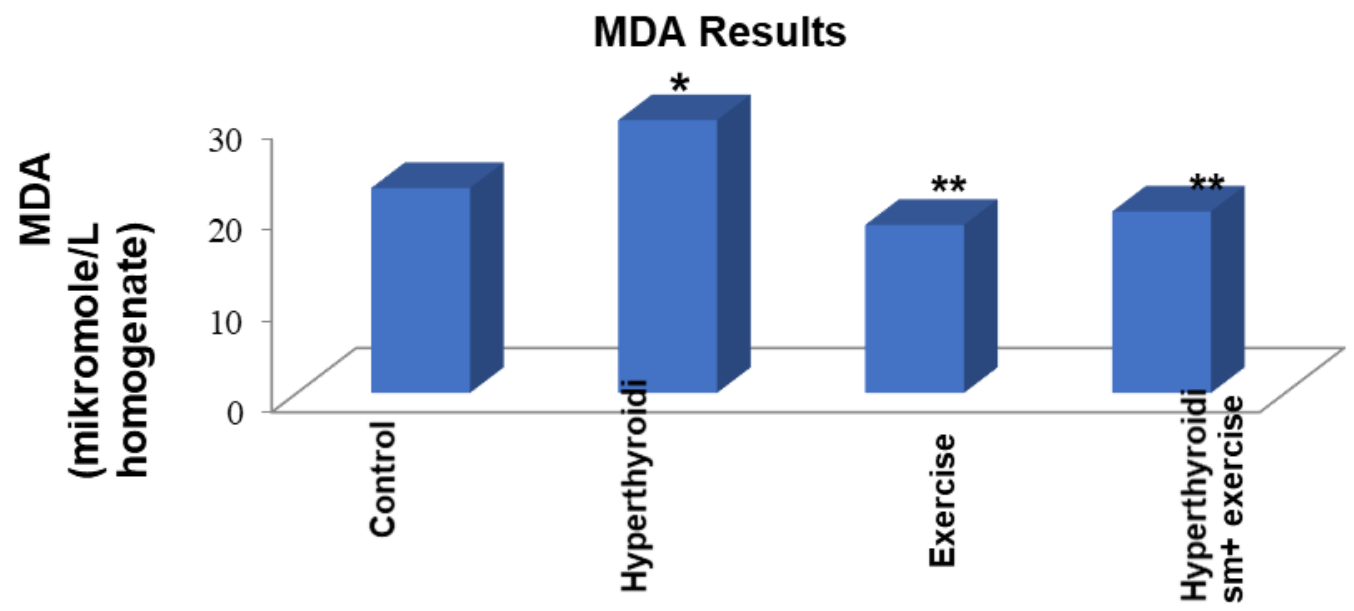

Figure 2. The MDA levels of rat kidney in control, hyperthyroidism, exercise, hyperthyroidism+ exercise groups. $* \mathrm{p}<0.005$ vs. Control, $* * \mathrm{p}<0.005$ vs. Hyperthyroidism (Mann Whitney Test results).

As shown in Table 2 and Figure 2, when kidney tissue MDA levels are compared, MDA levels of the hyperthyroidism group were found to be statistically significantly higher than the control group. When the other groups were compared with each other, there was a significant reduction in the MDA level of the exercise group compared to the hyperthyroidism group. The MDA level of the hyperthyroidism group was significantly higher than the hyperthyroidism+exercise group.

As shown in Table 2, Figure 3, and Figure 4, when kidney tissue GSH level and GSH-Px activity was compared between groups, it was found to be statistically significantly lower in the hyperthyroidism group compared to the control group. The exercise group's GSH level and GSH-Px enzyme activity appear to be significantly higher than the hyperthyroidism group.

\section{GSH-Px results}

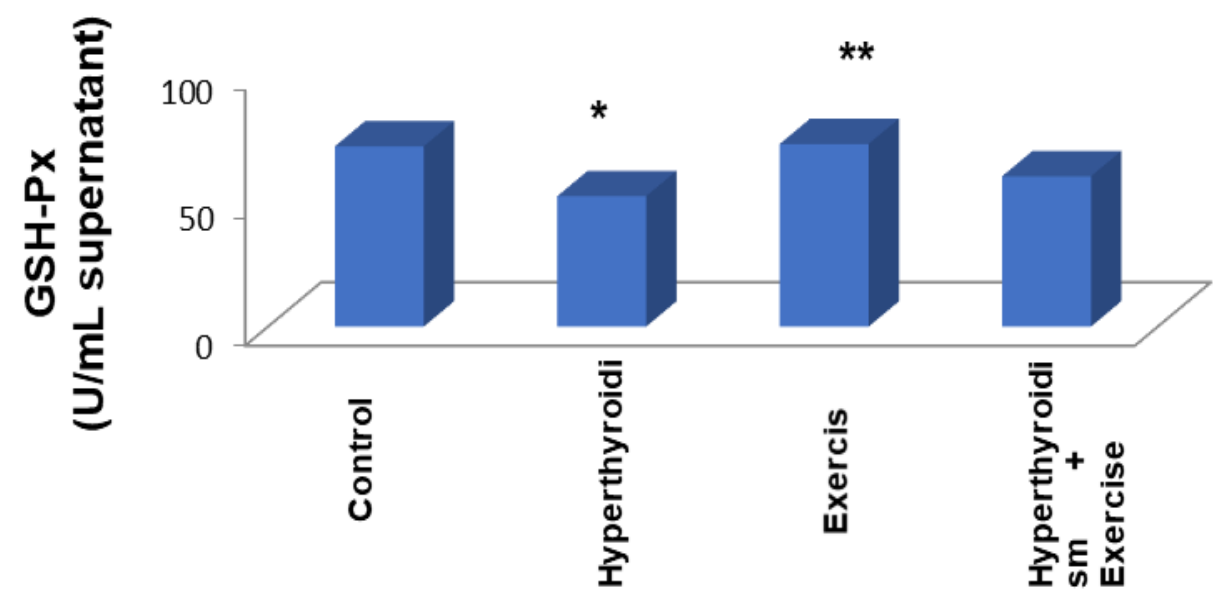

Figure 3. The GSH-Px activities in rat kidney tissues control, hyperthyroidism, exercise, hyperthyroidism+exercise groups. ${ }^{*} \mathrm{p}<0.005$ vs. Control, ${ }^{* *} \mathrm{p}<0.005$ vs. Hyperthyroidism (Mann Whitney Test results). 


\section{GSH results}

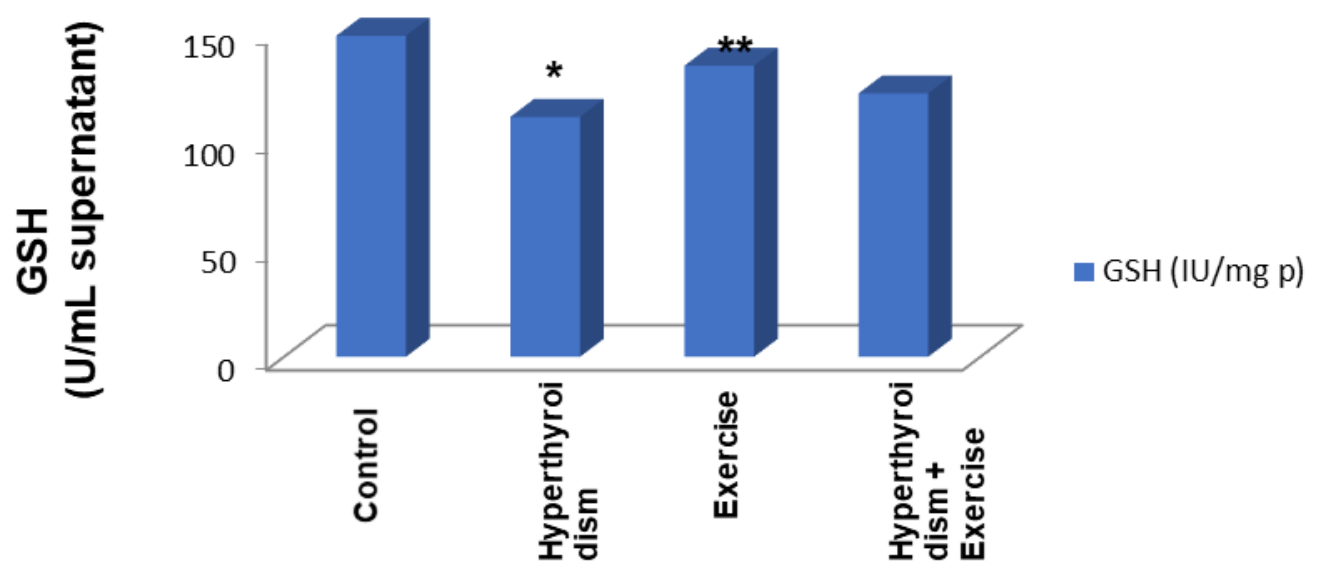

Figure 4. GSH levels in rat kidney tissues of control, hyperthyroidism, exercise, hyperthyroidism+exercise groups. ${ }^{*} \mathrm{p}<0.005$ vs. Control, $* * \mathrm{p}<0.005$ vs. Hyperthyroidism (Mann Whitney Test results).

\section{Discussion}

In this study, the effect of 8 weeks of endurance exercise on kidney tissue oxidant and antioxidant systems was examined in rats in which experimental hyperthyroidism was created with L-thyroxine. In recent years there has been an increasing interest in the effects of exercise on oxidative stress formation and antioxidant system.

The most important factor in this increasing interest is the change taking place in the oxidant and antioxidant capacity in relation to the type, duration and intensity of the exercise. Although there are some studies showing that training causes an increase in antioxidant enzyme capacity, the results are not clear $(16,17)$. Free oxygen radicals cause peroxidation of membrane phospholipids in many pathogeneses (6). It has been determined that free oxygen radicals induced by thyroid hormones in particular cause oxidative stress and ultimately increase lipid peroxidation. Lipid peroxidation caused by increased free radicals in patients with hyperthyroidism causes tissue damage and diseases to occur (18). The most widely used token as an in vivo indicator of oxidative damage is malondialdehyde, one of the breakdown products of lipid peroxidation caused by the reaction of free radicals with unsaturated fatty acids. The effects of thyroid hormones on lipid peroxidation have been the subject of research in many laboratories and conflicting results have been obtained. Some studies have shown that the addition of $\mathrm{T}_{3}$ (19) or long-term exercise (20) increases lipid peroxidation of the skeletal muscle, heart and liver tissue obtained from rats. In a study comparing the levels of erythrocyte antioxidant enzyme levels and serum MDA levels with data from the healthy control group of hyperthyroidism patients before and after treatment, MDA levels $(\mathrm{p}<0.05)$ which were high compared to pre-treatment control, were found to be close to the control values after treatment (7). In another recent study, it was reported that the total antioxidant capacity decreased and malondialdehyde levels increased in patients with hyperthyroidism compared to the control group (21). These findings suggest that the thyroid gland plays an important role in the production of oxidative stress in disease conditions. There are similar research studies that show high levels of plasma and tissue MDA in hyperthyroidism patients and experimental models in which hyperthyroidism has been developed $(3,22-25)$ In this study, in rat kidney tissue MDA levels show a significant increase in the hyperthyroidism group compared to the control group $(\mathrm{p}<0.05)$. When the other groups are compared to each other, it is observed that there is a significant reduction in the MDA level of the exercise group compared to the hyperthyroidism group $(\mathrm{p}=0.001)$. While Miyazaki et al. report that intensive endurance training can increase antioxidant enzyme capacity in erythrocytes together with aerobic capacity, Schneider et al. stated that they did not find a significant difference in both training and non-training subjects in lipid peroxidation and total antioxidant capacities before and after a moderate exercise $(26,27)$.

In light of all this information, that oxidative stress may play a role in physiopathology of hyperthyroidism is compatible with the high MDA values observed in our research along with the studies referenced above. It has been concluded that exercise can reduce oxidative stress although there are conflicting results in the studies in the literature.

According to the data of our research, GSH-Px, a peroxidase containing selenium that plays a critical role in the antioxidant system defense we have evaluated is produced against oxidative damage in mammalian cells (28). It allows the decarbonation of hydrogen peroxide using GSH. In our study GPx activity in kidney tissue has been determined as significantly low compared to the control group $(p<0.05)$, and statistically significantly higher compared to the exercise group $(\mathrm{p}<0.05)$. The majority of studies in the literature support increased GPx activity 
following acute and chronic exercise (29-31). This decrease in enzyme activity of the hyperthyroidism group is probably due to the response of the enzyme to oxidative stress during the removal of the increased $\mathrm{H}_{2} \mathrm{O}_{2}$ from the environment. While studies in the literature showing decreased GPx activity compared to the control group in the groups of patients (18) with hyperthyroidism and in rat tissue samples taken from rats in which experimental hyperthyroidism has been created show parallelism with our study; in human studies, there are studies that report high GPx activity in the control group compared to healthy individuals $(32,33)$. Increased GPx activity may be the result of a protective increase in the face of increased oxidative stress.

GSH is the most important non-enzymatic antioxidant molecule in the cell in that it protects cells against oxidant damage by reacting with free radicals and peroxides (34). In our study, when GSH measurements of the kidney tissue of the groups are evaluated, while the GSH level of the hyperthyroidism group shows a significant decrease in control group $(\mathrm{P}<0.05)$, GSH value of the exercise group was found to be significantly higher than the hyperthyroidism group $(\mathrm{P}<0.05)$. Low results $(\mathrm{p}<0.05)$ of $\mathrm{GSH}$ levels obtained in the group of patients with hyperthyroidism compared to the control group are consistent with the information in the literature (35-38). Venditti et al. investigated whether there was an effect of hyperthyroidism caused by $\mathrm{T}_{3}$ on oxidative damage and metabolism in rat muscles in swimming exercises, and have evaluated respiratory capacity, oxidative damage, antioxidant levels and sensitivity to oxidative change in tissue homogenates (39). With the data obtained, they have determined that the hormonal process caused oxidative damage to the rat muscle and decreased GSH level; on the other hand, they reported that all these effects were reduced by training. In light of all these results, they have suggested that oxidative damage linked to hyperthyroidism can be reduced with moderate training, there may be an increase in antioxidant production and a decrease in ROS flow from mitochondria to cytoplasmic compartment.

\section{Conclusions}

Hypermetabolic state in hyperthyroidism is associated with tissue oxidative damage. As a result, hyperthyroidism created by L-thyroxin injection increases oxidative stress in rat kidney tissue; nevertheless, endurance exercise tries to correct the balance deteriorating in favor of oxidants in the oxidant/antioxidant system. Regular endurance exercise has a lipid peroxidation-reducing effect and may have a positive effect on strengthening the antioxidant system in rats with hyperthyroidism. The existence of contradictory results in the studies conducted on this subject, however, since we could not find sufficient studies on this subject in the literature, it was not possible to compare our results one-to-one. Therefore, we think that further studies are needed.

\section{Ethics approval}

All procedures and protocols used in the study were in accordance with the National Council of Animal Experimentation (CONCEA) and It was approved by the Local Ethics Board of Animal Experiments at Ataturk University, with the document numbered: B.30.2.ATA.0.A1.-2465 that all stages of the study comply with the ethical rules.

\section{Acknowledgment}

This article is prepared from master thesis.

\section{References}

1. Dolorres S, DG G. Greenspan's basic \& clinical endocrinology. New York: McGraw-Hill Medical; 2011.

2. Hall JE, Hall ME. Guyton and Hall textbook of medical physiology e-Book: Elsevier Health Sciences; 2020.

3. Venditti P, Di Meo S. Thyroid hormone-induced oxidative stress. Cellular and Molecular Life Sciences CMLS. 2006;63(4):414-34.

4. Mancini A, Di Segni C, Raimondo S, Olivieri G, Silvestrini A, Meucci E, et al. Thyroid Hormones, Oxidative Stress, and Inflammation. Mediators of Inflammation. 2016;2016:6757154.

5. Ourique GM, Finamor IA, Saccol EM, Riffel AP, Pês TS, Gutierrez K, et al. Resveratrol improves sperm motility, prevents lipid peroxidation and enhances antioxidant defences in the testes of hyperthyroid rats. 2013;37:31-9.

6. Bianchi G, Solaroli E, Zaccheroni Vaa, Grossi G, Bargossi A, Melchionda N, et al. Oxidative Stress and Anti-Oxidant Metabolites in Patients with Hyperthyroidism: Effect of Treatement. Hormone and metabolic research. 1999;31(11):620-4.

7. Gutteridge J. Lipid peroxidation and antioxidants as biomarkers of tissue damage. Clinical chemistry. 1995;41(12):1819-28.

8. Onat T, Kaya E, Sözmen E. İnsan biyokimyası. 2'inci baskı. Ankara, Palme Yayıncılık. 2006;9:518-22.

9. Seven A, Candan G. Antioksidan savunma sistemleri. Cerrahpaşa Tıp Dergisi. 1996;27(1):41-50.

10. Ji LL. Antioxidants and oxidative stress in exercise. Proceedings of the Society for experimental Biology 
and Medicine. 1999;222(3):283-92.

11. Revan S, AE E. Farklı dayanıklılık antrenmanlarının oksidatif stres oluşumu ve antioksidan düzeyleri üzerine etkisi. Gazi Üniversitesi, Sağlık Bilimleri Enstitüsü, Ankara. 2007.

12. Ayala C, Valdez SR, Morero MLN, Soaje M, Carreño NB, Sanchez MS, et al. Hypo-and hyperthyroidism affect NEI concentration in discrete brain areas of adult male rats. 2011;32(6):1249-54.

13. Messarah M, Saoudi M, Boumendjel A, Boulakoud MS, El Feki AJet, pharmacology. Oxidative stress induced by thyroid dysfunction in rat erythrocytes and heart. 2011;31(1):33-41.

14. Pereira B, Rosa LC, Safi D, Bechara E, Curi RJJoE. Control of superoxide dismutase, catalase and glutathione peroxidase activities in rat lymphoid organs by thyroid hormones. 1994;140(1):73-7.

15. Ohkawa H, Ohishi N, Yagi K. Assay for lipid peroxides in animal tissues by thiobarbituric acid reaction. Analytical biochemistry. 1979;95(2):351-8.

16. Mcbride JM, Kraemer WJ. Free radicals, exercise, and antioxidants. The Journal of Strength \& Conditioning Research. 1999;13(2):175-83.

17. Oh-ishi S, Kizaki T, Ookawara T, Toshinai K, Haga S, Karasawa F, et al. The effect of exhaustive exercise on the antioxidant enzyme system in skeletal muscle from calcium-deficient rats. Pflügers Archiv. 1998;435(6):767-74.

18. Gür B, Halifeoğlu İ, Telo S, Tolun Fİ. Hipertiroid hastalarda tedavi öncesi ve sonrasi malondialdehit ve antioksidan enzim düzeyleri. Fırat Üniversitesi Sağlık Bilimleri Dergisi. 2005;19:221-6.

19. Fernández V, Tapia G, Varela P, Videla LA. Redox regulation of thyroid hormone-induced Kupffer celldependent I $\mathrm{KB}-\alpha$ phosphorylation in relation to inducible nitric oxide synthase expression. Free radical research. 2005;39(4):411-8.

20. Venditti P, De Rosa R, Caldarone G, Di Meo S. Effect of prolonged exercise on oxidative damage and susceptibility to oxidants of rat tissues in severe hyperthyroidism. Archives of biochemistry and biophysics. 2005;442(2):229-37.

21. Olia BH, Khadem Ansari MH, Rasmi Y, Hasanzadeh-Moghadam M. Evaluation of Malondialdehyde Levels and Total Antioxidant Capacity in Patients with Hyperthyroidism. 2019.

22. Assaei R, Zal F, Mostafavi-Pour Z, Dabbaghmanesh MH, Geramizadeh B, Omrani GHR, et al. Hepatoprotective effect of Satureja khuzestanica essential oil and vitamin E in experimental hyperthyroid rats: evidence for role of antioxidant effect. Iranian journal of medical sciences. 2014;39(5):459.

23. Rybus-Kalinowska B, Zwirska-Korczala K, Kalinowski M, Kukla M, Birkner E, Jochem J. Activity of antioxidative enzymes and concentration of malondialdehyde as oxidative status markers in women with newly diagnosed Graves-Basedow disease and after thiamazole therapy leading to euthyroidism. Pol Arch Med Wewn. 2008;118(7-8):420-5.

24. Yildirim S, Yildirim A, Dane S, Aliyev E, Yigitoglu R. Dose-dependent protective effect of L-carnitine on oxidative stress in the livers of hyperthyroid rats. The Eurasian journal of medicine. 2013;45(1):1.

25. Ramadan HM, Taha NA, Ahmed HH. Melatonin enhances antioxidant defenses but could not ameliorate the reproductive disorders in induced hyperthyroidism model in male rats. Environmental Science and Pollution Research. 2021;28(4):4790-804.

26. Miyazaki H. Oh-ishi S, Ookawara T, Kizaki T, Toshinai K, Ha S, Haga S, Ji LL, and Ohno H. Strenuous endurance training in humans reduces oxidative stress following exhausting exercise Eur J Appl Physiol. 2001;84:1-6.

27. Schneider CD, Barp J, Ribeiro JL, Belló-Klein A, Oliveira AR. Oxidative stress after three different intensities of running. Canadian journal of applied physiology. 2005;30(6):723-34.

28. Matés JM, Sánchez-Jiménez FJFB. Antioxidant enzymes and their implications in pathophysiologic processes. 1999;4(4):D339-D45.

29. Mangner N, Linke A, Oberbach A, Kullnick Y, Gielen S, Sandri M, et al. Exercise training prevents TNFainduced loss of force in the diaphragm of mice. PLoS One. 2013;8(1):e52274.

30. Ristow M, Zarse K, Oberbach A, Klöting N, Birringer M, Kiehntopf M, et al. Antioxidants prevent healthpromoting effects of physical exercise in humans. Proceedings of the National Academy of Sciences. 2009; $106(21): 8665-70$.

31. Smuder AJ, Kavazis AN, Min K, Powers SK. Exercise protects against doxorubicin-induced oxidative stress and proteolysis in skeletal muscle. Journal of Applied Physiology. 2011;110(4):935-42.

32. Andryskowski G, Owczarek T. The evaluation of selected oxidative stress parameters in patients with hyperthyroidism. Polskie Archiwum Medycyny Wewnetrznej. 2007;117(7):285.

33. Rostami R, Aghasi M, Mohammadi A, Nourooz-Zadeh J. Enhanced oxidative stress in Hashimoto's thyroiditis: inter-relationships to biomarkers of thyroid function. Clinical biochemistry. 2013;46(4-5):30812.

34. Gürdol F, Ademoğlu E. Biyokimya. Nobel tıp kitabevleri. 2010;2.

35. Adali $\mathrm{M}$, İnal-erden $\dot{\mathrm{M}}$, Akalin $\mathrm{A}$, Efe Bn. Effects of propylthiouracil, propranolol, and vitamin $\mathrm{E}$ on lipid 
peroxidation and antioxidant status in hyperthyroid patients. Clinical biochemistry. 1999;32(5):363-7.

36. Araujo A, Seibel F, Oliveira U, Fernandes T, Llesuy S, Kucharski L, et al. Thyroid hormone-induced haemoglobin changes and antioxidant enzymes response in erythrocytes. Cell biochemistry and function. 2011;29(5):408-13.

37. Kumar KM, Bobby Z, Selvaraj N, Das AK, Koner BC, Sen S, et al. Possible link between glycated hemoglobin and lipid peroxidation in hyperthyroidism. Clinica chimica acta. 2004;342(1-2):187-92.

38. Venditti P, Bari A, Di Stefano L, Di Meo S. Role of mitochondria in exercise-induced oxidative stress in skeletal muscle from hyperthyroid rats. Archives of Biochemistry and Biophysics. 2007;463(1):12-8.

39. Venditti P, Bari A, Di Stefano L, Di Meo S. Effect of T3 on metabolic response and oxidative stress in skeletal muscle from sedentary and trained rats. Free Radical Biology and Medicine. 2009;46(3):360-6. 